\title{
Establishing Modern Bachelor-level Studies in Computer Science based on Higher Education Standard in Ukraine
}

\author{
Kovaliuk Tetiana ${ }^{1}$, Kobets Nataliya ${ }^{2}$ \\ ${ }^{1}$ Taras Shevchenko National University of Kyiv, 64/13, Volodymyrska Str, Kyiv, 01601 Ukraine \\ ${ }^{2}$ Borys Grinchenko Kyiv University, 18/2 Bulvarno-Kudriavska Str, Kyiv, 04053, Ukraine
}

How to cite this paper: T. Kovaliuk, N Kobets. (2020) Establishing Modern Bachelor-level Studies in Computer Science based on Higher Education Standard in Ukraine. The Educational Review, USA, 4(3), 66-80.

DOI: $10.26855 /$ er.2020.03.003

Received: June 5, 2019

Accepted: June 27, 2019

Published: March 10, 2020

\begin{abstract}
The work considers the Computer Science standard for Bachelor's Degree Programs in Ukraine in the context of harmonizing its content with world practice. The CS standard defines the subject area description, which includes the object of activity, goals and objectives of training, the theoretical content of the domain, teaching methods and technologies. The competency-based model for the bachelors training in computer science is described, This model includes generic and subject specific competencies, learning outcomes. Relation generic competencies of CS educational standard and descriptors of Ukrainian NQF is shown. The methodology for developing the educational standard of the Bachelor of Computer Science is based on the systematization of the IT industry requirements to the competencies of alumnus. CS standard is approved by the Ministries of Education and Science of Ukraine and is mandatory for implementation in the educational practice of all universities.
\end{abstract}

*Corresponding author: Taras Shevchenko National University of Kyiv, Ukraine.

Email:

${ }^{1}$ tetyana.kovalyuk@gmail.com,

2nmkobets@gmail.com

\section{Keywords}

Computer Science, Competencies, Learning Outcomes, Educational Program

\section{Introduction}

Information Technology (IT) forms the basis of any developed economy. Information and Communication Technologies are identified as a priority direction of economic development for the period up to 2020 in accordance with the Law of Ukraine on "Priority directions of science and technology development" [1]. IT is one of the most dynamic and successful industries in Ukraine and is a major source of competitive advantage for business entities in the digital economy era. A successful development strategy in the context of the "knowledge economy" hinges on high quality of human capital that generates transforms and multiplies the intangible assets of the organization.

Qualified professionals are the main IT resource. Their insufficient quantity and quality are one of the main constraints on the development of this sector of the economy. The market demand for Information Systems and Technology specialists is growing every day; their role in improvement of the efficiency of Ukrainian economy is on the rise. IT industry requirements for information technology specialists are formulated in the form of competencies. These competencies are a set of requirements regarding possession of a large range of modern information technology, skills of modelling, programming and support of information systems, understanding the subject area, the ability to analyze 
and optimize automated business processes and the tasks of organizational management, methods and technologies of project management and to undertake management decisions.

Computer science is the core of theoretical and practical knowledge that specialists in the field of computer engineering, programming, information systems and technologies use in their work.

One of the components of the country's labor potential qualitative attribute is the level of education and knowledge across individuals. Education and training are factors contributing to a society of well-qualified, dynamic and creative people where opportunities for good education and lifelong learning are accessible for everyone and where a favorable environment is created for a rational combination of public and private funding. Tailoring the modern methods of knowledge management to the needs of educational institutions helps accumulating knowledge in subject areas in a meaningful way and effectively transferring this knowledge to the future specialists.

\section{Indicators of development and staffing problems of the IT ind ustry of Ukraine}

Software development industry of Ukrainian is among the country's fastest growing sectors. Tech companies in Ukraine ensure a steady capital inflow into the country's economy, attracting foreign investments and paying fair taxes. They help create a systemic demand for consumer services and goods in the field of education, insurance, healthcare, real estate, etc. At large, one IT specialist creates 4 different jobs in other related industries. Judging from the dynamics of the IT market growth, 2020 will see major growth in the number of local tech companies and IT specialists. International investors will discover Ukraine as the most favorable country to set up a dedicated development team. With the solid technical education, a large pool of engineering talent and a booming tech ecosystem, Ukraine has all chances to become the world's largest destination in the tech industry [2].

The total volume of IT exports from Ukraine by the end of 2018 was $\$ 4.5$ billion [3]. Ukraine has become Europe's \#1 IT outsourcing and software development powerhouse. Nearly 100,000 Ukrainian programmers serve thousands of companies as the demand for IT workforce is constantly growing on the global market.

Key findings Ukraine's IT service industry [4]:

Ukraine has the largest and fastest-growing number of IT professionals in Europe; its IT engineering work force is expected to double to over 200,000 by 2020 .

Ukrainian outsourcing companies offer a wide range of engineering capabilities, with most companies having already switched to agile development over the past few years.

The export volume of Ukraine's software development industry reached at least $\$ 4.5$ billion in 2018 (number 3 export sector), showing double digit growth year after year. This is just a fraction of the country's potential, taking into account its large and skilled workforce.

Ukraine is home to over 100 R\&D subsidiaries of global companies from a variety of industries, including telecoms, software, gaming and e-commerce.

The United States remains Ukraine's largest partner for joint R\&D activities (around 45\% of the companies involved). Despite the fact that the IT profession is the most prestigious in Ukraine, there is a shortage of highly qualified personnel in Ukraine. The number of vacancies in IT companies has reached 50 thousand on 2018. Considering that the total number of school graduates in 2018 was 200 thousand, it is impossible to count on the fact that the demand for IT specialists in the near future will be satisfied.

\section{Harmonization of IT Bachelors training in Ukraine with world practice}

ACM Recommendations for Computing Curricula 2005/2017 developed by Association for Computing Machinery 
(ACM), IEEE-Computer Society and Association for Information Systems (AIS) are the methodological basis of IT education of Ukraine. Harmonization of training for IT industry of Ukraine with world practice is carried out in the specialties of Bachelor's degree [5].

Including accepted in Europe IT courses of study to domestic higher educational system ensures its succession and harmonization with European IT educational programs which is transparent to IT industry, open to qualification and advanced training in terms of Double Degree and Academic Mobility of students, postgraduates and professors. According to international Computing Curricula recommendation, IT education in Ukraine includes the following specialties (Table 1) [6,7].

Table 1. IT Education Specialties in Ukraine

\begin{tabular}{ccc}
\hline Knowledge code and area & Specialty code & Specialty title \\
\hline 121 & 122 & Software Engineering \\
12 Information Technology & 123 & Computer Science \\
124 & Computer Engineering \\
125 & System analysis \\
126 & Cybersecurity \\
\hline
\end{tabular}

The Ministry of Education and Science of Ukraine approved higher education standards for these specialties during 2017-2019. Here's we consider the Computer Science standard for Bachelor's Degree Programs.

\section{Subject area description of Computer Science Bachelor's Standard}

The methodological basis for defining the contents of the Bachelor's curriculum for the Ukrainian Educational Standard was the Curricula Recommendations from the Association for Computing Machinery (ACM). Body of knowledge and set of competencies contained in the document "Curriculum Guidelines for Undergraduate Degree Programs in Computer Science" [8]. Ukrainian Educational Standard on specialty in Computer Science defines subject area description (Table 2) according to the Guidelines on the development of Higher Education Standards [9].

\section{Competency Model for Bachelor's Degree Programs in Computer Science}

Competence-based approach and assessment of learning outcomes in accordance with the "Tuning Educational Structures in Europe" project, laid the foundation for the development of Computer Science training program. According to the Tuning methodology, the learning outcomes are statements of what a learner is expected to know, understand and/or be able to demonstrate after completion of learning. Learning outcomes are formulated in terms of competencies. Competency is a dynamic combination of knowledge, hard and soft skills, ways of thinking, professional, ideological and civic qualities, moral and ethical values, which determines a person's ability to successfully carry out professional and further educational activities and is the result of learning at a certain level of higher education [10]. The development of competencies is the goal of educational programs. The main difference between learning outcomes and competencies is that teachers both at the curriculum level and for a separate discipline formulate the former, while the learners acquire the competencies [11].

Competencies and skills are understood as including knowing and understanding (theoretical knowledge of an academic 
Table 2. Subject area description of CS Bachelor's standard

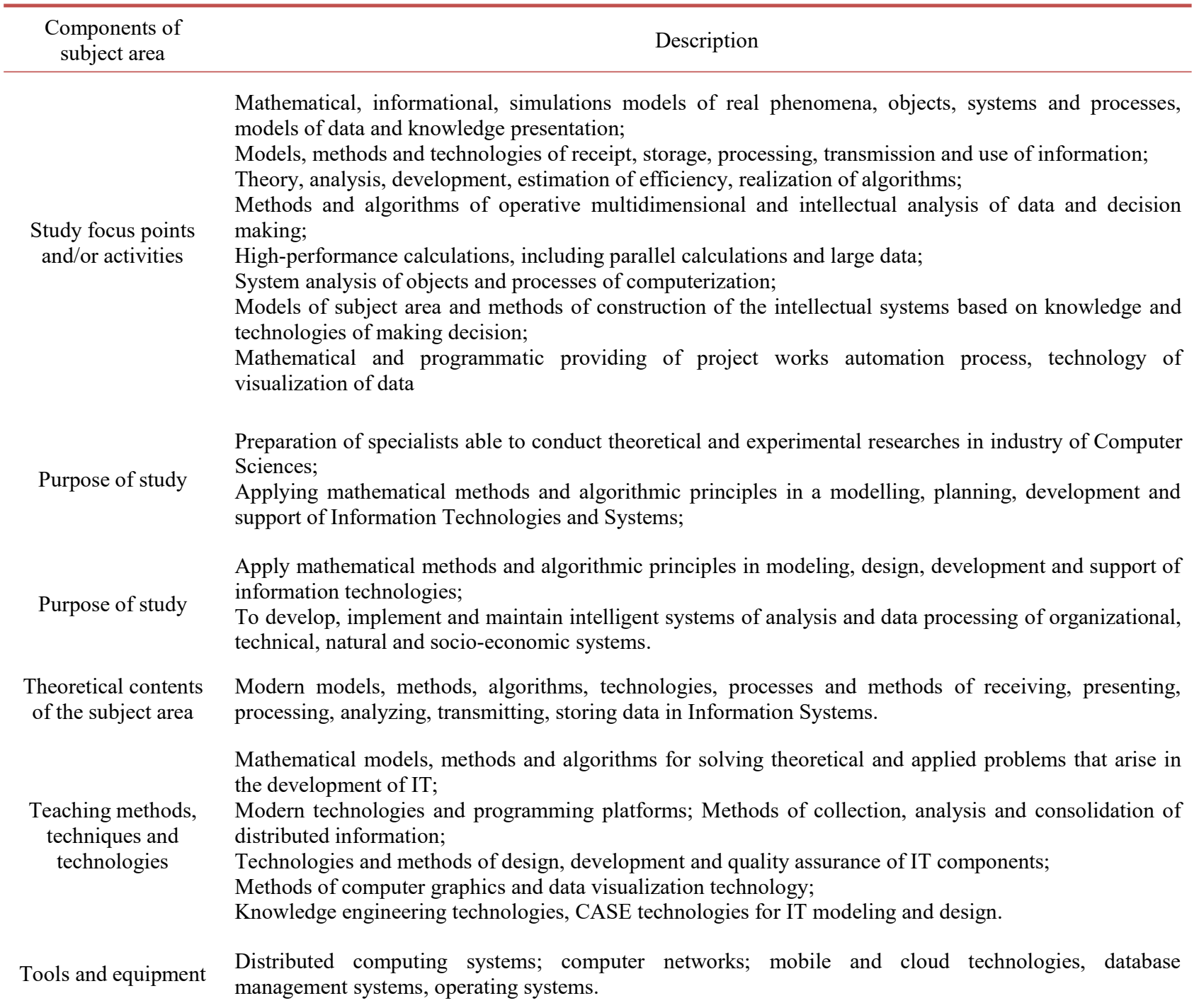

Number of ECTS credits required for a bachelor's degree is 240 based on complete general secondary education with 11 years study period.

field, the capacity to know and understand), knowing how to act (practical and operational application of knowledge to certain situations), knowing how to be (values as an integral element of the way of perceiving and living with others and in a social context). Competencies represent a combination of attributes (with respect to knowledge and its application, attitudes, skills and responsibilities) that describe the level or degree to which a person is capable of performing them [12].

\subsection{Integrated competence}

According to the National qualifications framework of Ukraine, Bachelor is able to solve complex specific tasks and practical problems in a particular professional area or during training process that involves application of certain theories and methods of a relevant science and is characterized by complexity and uncertainty of conditions. 


\subsection{Generic competencies}

Competence-based approach and assessment of learning outcomes in accordance with the "Tuning Educational Structures in Europe" project, laid the foundation for the development of CS educational standard. According to the Tuning methodology, the learning outcomes are statements of what a learner is expected to know, understand and/or be able to demonstrate after completion of learning. Learning outcomes are formulated in terms of competencies. Competency is a dynamic combination of knowledge, hard and soft skills, ways of thinking, professional, ideological and civic qualities, moral and ethical values, which determines a person's ability to successfully carry out professional and further educational activities and is the result of learning at a certain level of higher education [13]. The development of competencies is the goal of educational programs. The main difference between learning outcomes and competencies is that teachers both at the curriculum level and for a separate discipline formulate the former, while the learners acquire the competencies.

In accordance with the "Tuning Educational Structures in Europe" project, the following generic competencies were identified:

- GC1. Ability to abstract thinking, analysis and synthesis.

- GC2. Ability to apply knowledge in practical situations.

- GC3. Knowledge and understanding of the subject area of the professional activity.

- GC4. Ability to communicate with experts verbally and in writing.

- GC5. Knowledge of a second language.

- GC6. Ability to learn and stay up-to-date with learning.

- GC7. Ability to search for, process and analyses information from a variety of sources.

- GC8. Ability to generate new ideas (creativity).

- GC9. Ability to teamwork.

- GC10. Critical and self-critical abilities.

- GC11. Ability to project design and management.

- GC12. Ability to make reasoned decisions.

- GC13. Ability to evaluate and maintain the quality of work produced.

- GC14. Determination and perseverance in the tasks given and responsibilities taken.

- GC15. Ability to act based on ethical reasoning.

\subsection{Subject specific competencies}

In addition to the generic competencies learning programme seek to foster more specific subject competencies (skills and knowledge). The subject related skills are the relevant methods and techniques pertaining to the various discipline areas. The educational standard of Ukraine in Computer Science defines such subject specific competencies:

- SC1. Ability to mathematically formulation and research of continuous and discrete mathematical models, substantiation of the choice of methods and approaches for solving theoretical and applied problems in computer science, analysis and interpretation.

- SC2. Ability to detect statistical patterns of non-deterministic phenomena, application of computational intelligence methods, including statistical, neural network and fuzzy data processing, machine learning and genetic programming and like.

- SC3. Ability to logical thinking, construct logical conclusions, use formal languages and algorithmic calculation models, design, development and analysis of algorithms, evaluate their efficiency and complexity, solvability and 
insolvability of algorithmic problems for adequate modeling of subject areas and creation of software and information systems.

- SC4. Ability to use modern methods of mathematical modeling of objects, processes and phenomena, to develop models and algorithms for numerical separation of the tasks of mathematical modeling, to take into account the errors of the approximate numerical solution of professional problems.

- SC5. Ability to carry out a formalized description of operations research tasks in organizational, technical and socio-economic systems for various purposes, to determine their optimal solutions, to build optimal management models taking into account changes in the economic situation, to optimize management processes in various systems and hierarchy level.

- SC6. Ability to systemic thinking, to apply the methodology of system analysis to study complex problems of different nature, methods of formalizing and solving system problems that have conflicting goals, uncertainties and risks.

- SC7. Ability to apply the theoretical and practical foundations of modeling methodology and technology to study the characteristics and behavior of complex objects and systems, to perform computational experiments with the processing and analysis of results.

- SC8. Ability to design and develop software using different programming paradigms: generalized, object-oriented, functional, logical, with appropriate models, calculation methods and algorithms, data structures and control mechanisms.

- SC9. Ability to implement a multi-level computing model based on client-server architecture, including databases, knowledge, and data warehouses, to perform distributed processing of large datasets on clusters of servers to meet the computing needs of users, including cloud services.

- SC10. Ability to apply methodologies, technologies and tools to manage the lifecycle of information and software systems, products and services of information technology in accordance with customer requirements.

- SC11. Ability to data mining based on computational intelligence methods, including large and poorly structured data, their on-line processing and visualization of analysis results in the process of solving applied problems.

- SC12. Ability to provide the organization of computing processes in information systems for various purposes, taking into account the architecture, configuration, performance indicators of the functioning of operating systems and system software.

- SC13. The ability to develop networked software that operates on different topologies of structured cabling systems uses computer systems and data networks and analyzes the quality of computer networks.

- SK14. Ability to apply information security methods and tools, to develop and operate specialized software to protect the information resources of critical information infrastructure objects.

- SC15. Ability to analyze and functional modeling of business processes, the construction and practical application of functional models of organizational, economic and industrial-technical systems, risk assessment methods for their design.

- SC16. Ability to implement high-performance computing based on cloud services and technologies, parallel and distributed computing in the development and operation of distributed parallel processing systems.

\subsection{Programme learning outcomes}

Programmed learning outcomes are what the student needs to know, understand and be able to demonstrate after graduation. Learning outcomes determine credit award requirements. 
The educational standard of Ukraine in Computer Science determines such programmed learning outcomes:

- LO1. To apply fundamental knowledge of basic forms and laws of abstract logical thinking, basics of scientific knowledge methodology, forms and methods of exclusion, analysis, processing and synthesis of information in computer science subject area.

- LO2. To use the modern mathematical apparatus of continuous and discrete analysis, linear algebra, analytical geometry for solving theoretical and applied problems in design and implementation of information objects.

- LO3. To use knowledge of the laws of random phenomena, their properties and operations on them, models of random processes and modern software environments for solving problems of statistical data processing and construction of predictive models.

- LO4. To use methods of computational intelligence, machine learning, neural network and fuzzy data processing, genetic and evolutionary programming to solve the problems of recognition, prediction, classification, identification of control objects, etc.

- LO5. To design, develop and analyze algorithms for solving computational and logical problems, evaluate the efficiency and complexity of algorithms based on the application of algorithms formal models and calculated functions.

- LO6. To use methods of numerical differentiation and integration of functions, solution of ordinary differential and integral equations, peculiarities of numerical methods and possibilities of their adaptation to engineering problems, have skills of software implementation of numerical methods.

- LO7. To understand the principles of modeling organizational and technical systems and operations; to use operations research methods, solving single- and multi-criteria optimization problems of linear, integer, nonlinear, stochastic programming.

- LO8. To use the methodology of system analysis of objects, processes and systems for the tasks of analysis, forecasting, management and design of dynamic processes in macroeconomic, technical, technological and financial objects.

- LO9. To develop software models of subject environments, to choose a programming paradigm from the standpoint of convenience and quality of application for the implementation of methods and algorithms for solving problems in computer science.

- LO10. To use client-server application development tools, design conceptual, logical and physical database models, design and optimize queries, create distributed databases, data warehousing and showcases, knowledge bases, including on cloud services, using web-based languages.

- LO11. To have the skills to manage the software lifecycle, products and services of information technologies in accordance with the requirements and limitations of the customer, be able to develop project documentation (feasibility study, terms of reference, business plan, agreement, and contract).

- LO12. To apply the methods and algorithms of computational intelligence and data mining in problems of classification, forecasting, cluster analysis, finding associative rules using software tools to support multidimensional data analysis based on technologies Data Mining, Text Mining, Web Mining.

- LO13. To know the system programming languages and software programs development methods that interact with components of computer systems, to demonstrate knowledge of network technologies, architecture of computer networks and practical skills in technology management of computer networks and their software.

- LO14. To apply knowledge of methodologies and CASE-means of designing the complex systems, methods of structural analysis of systems, object-oriented design methodology in the process of construction and practical 
application of functional models of organizational and economic, production and technical systems.

- LO15. To demonstrate knowledge of information security concepts, principles of safety software design, to ensure the safety of computer networks in conditions of uncertainty and incomplete source data.

- LO16. To perform parallel and distributed computations, apply numerical methods and algorithms for parallel structures, parallel programming languages for the development and operation of parallel and distributed software.

\section{The forms of higher education applicants certification}

The final state attestation is performed in the form of defense the graduate qualification work of the bachelor (diploma project or work).

Qualification work should involve a theoretical, systematic or experimental study of a complex specialized or practical problem in computer science area, characterized by the complexity and uncertainty of the conditions and the application of information technology theories and methods.

Qualification work cannot have academic plagiarism, falsification and fabrication. The qualification work must be published on the official website of the higher education institution or its structural unit, or in the repository of the higher education institution.

\section{Requirements for internal quality of higher education system}

HEI should provide the quality assurance system of the educational activities and quality of higher education (system of internal quality assurance), which includes the following procedures and measures [14, 15]:

1. Determination of principles and procedures for quality assurance of higher education.

2. Monitoring and periodic review of education programs.

3. Annual evaluation of students, research and teaching staff of higher educational institution and regular publication of the results of such assessments on the official website of the HEI, on notice boards and in any other way.

4. Providing the skills upgrading of educational and scientific employees in the form of training or pass courses with obtaining relevant supporting documents at least once every five years or by defense of a thesis.

5. Providing the necessary resources for the educational process, including independent work of students at each educational program.

6. Providing the availability of information systems for the efficient management of the educational process.

7. Attracting educational sector employers to participate in the preparation and implementation of educational programs of specialty 122 "Computer science" and its specializations, coordination with them educational and professional standards.

8. Providing the publicity of information about educational programs, higher education degrees and qualification.

9. Development practices of academic honesty, specifically providing an effective system of prevention and detection of plagiarism in scientific works of HEI employees and students.

The quality assurance system for higher education and quality of higher education (internal quality assurance system) is evaluated by the National Agency for Quality Assurance in Higher Education or by accredited independent institutions. The quality of higher education in Ukraine must meet the requirements of the National Agency for Quality Assurance in Higher Education, international standards and recommendations for the quality assurance of higher education.

\section{Relation of generic competencies of CS Bachelor's standard with descriptors of national qualification framework of Ukraine}


The National Qualifications Framework (NQF) is intended for use by executive organizations that implement public policy in the sphere of education, employment and social-labor relations, educational institutions, employers and other entities and individuals to elaborate, identify, correlate, recognize, plan and develop qualifications.

For the purposes of the National Qualifications Framework the terms shall have the following meanings [16]:

knowledge - meaningful scientific information learnt by a person, which is the basis of his/her conscious, purposeful activity;

skills - ability to apply knowledge in order to perform tasks and resolve problems and issues;

autonomy and responsibility - ability to independently perform tasks, solve problems and issues, and take responsibility for the activities results;

communication - interrelation of agents targeted at information transfer, actions coordination, joint activities.

The relation of generic competencies of CS Bachelor's standard with descriptors of national qualification framework of Ukraine is presented in table 3.

Table 3. Generic competencies and descriptors of NQF

\begin{tabular}{llll}
\hline Knowledge & Skills & Communication & $\begin{array}{l}\text { Autonomy } \\
\text { responsibility }\end{array}$
\end{tabular}

GC1. Ability to abstract thinking, analysis and synthesis

A knowledge of the basic forms and laws of the abstract-logical thinking, basics of the logic, critical approach standards, basics of the methodology of the science knowledge, forms and methods of the analysis and synthesis
Gaining systematic knowledge in computer science, analyzing the problem in terms of current scientific paradigms, interpreting and making reasonable conclusions from scientific literature and experimental results
Implementation of social communication in the process of communicating The responsibility for with specialists and non-specialists in computer science, ensuring the exchange of logical arguments to achieve mutual understanding and assigned work, autonomy in decision-making on solving problems in computer science

GC2. Ability to apply knowledge in practical situations.

GC3. Knowledge and understanding of the subject area and profession activity

\begin{tabular}{|c|c|c|c|}
\hline $\begin{array}{l}\text { A knowledge of teaching } \\
\text { methods, organization and } \\
\text { implementation, promotion } \\
\text { and motivation of teaching and } \\
\text { learning of understanding } \\
\text { computer science area. }\end{array}$ & $\begin{array}{l}\text { Implementation of learned } \\
\text { concepts, theories and } \\
\text { methods of the intellectual } \\
\text { and practical activities in } \\
\text { computer science, } \\
\text { reflection of the content } \\
\text { and sequence of ways for } \\
\text { performing actions } \\
\text { summarizing and } \\
\text { organizing the results of } \\
\text { work. }\end{array}$ & $\begin{array}{l}\text { The ability to sociability, } \\
\text { emotional stability, } \\
\text { endurance, stroke, } \\
\text { defending own point of } \\
\text { view, clear expression of } \\
\text { their opinions. }\end{array}$ & $\begin{array}{l}\text { Ability to organize the } \\
\text { work to achieve results, } \\
\text { performance and } \\
\text { mental and practical } \\
\text { actions, methods and } \\
\text { operations of awareness } \\
\text { of responsibility for } \\
\text { their activities, the use } \\
\text { of self-monitoring and } \\
\text { self-evaluation. }\end{array}$ \\
\hline
\end{tabular}

GC4. Ability to communicate with experts verbally and in writing.

GC5. Knowledge of a second language.

\begin{tabular}{llll}
\hline $\begin{array}{l}\text { A knowledge of lexical, } \\
\text { grammatical and stylistic }\end{array}$ & $\begin{array}{l}\text { Professionally meeting } \\
\text { state and foreign }\end{array}$ & $\begin{array}{l}\text { Possession and usage of } \\
\text { typical professional }\end{array}$ & $\begin{array}{l}\text { The responsibility for } \\
\text { an accuracy and }\end{array}$ \\
$\begin{array}{l}\text { features of state and foreign } \\
\text { vocabulary, computer science } \\
\text { terminology, grammar to }\end{array}$ & $\begin{array}{l}\text { languages, developing the } \\
\text { state and foreign languages } \\
\text { cor documentation systems, }\end{array}$ & $\begin{array}{l}\text { and syntactic models, } \\
\text { building communication }\end{array}$ & $\begin{array}{l}\text { correctness of the } \\
\text { statements in official } \\
\text { and foreign languages }\end{array}$ \\
\hline
\end{tabular}




\begin{tabular}{llll}
\hline Knowledge & Skills & Communication & $\begin{array}{l}\text { Autonomy } \\
\text { responsibility }\end{array}$ \\
\hline $\begin{array}{l}\text { understand and produce oral } \\
\text { and written foreign texts in } \\
\text { professional field }\end{array}$ & $\begin{array}{l}\text { products and services } \\
\text { information technology to } \\
\text { read, understand and use } \\
\text { technical documentation in } \\
\text { Ukrainian and foreign } \\
\text { languages in professional } \\
\text { activity. }\end{array}$ & $\begin{array}{l}\text { in speech and writing } \\
\text { state and foreign } \\
\text { languages, based on the } \\
\text { objectives and the } \\
\text { situation of } \\
\text { communication. }\end{array}$ \\
& & & \\
\hline
\end{tabular}

GC6. Ability to learn and stay up-to-date with learning

\begin{tabular}{|c|c|c|c|}
\hline $\begin{array}{l}\text { A knowledge of techniques } \\
\text { and teaching methods, } \\
\text { self-education methods, basic } \\
\text { scientific and research } \\
\text { activities, methods of } \\
\text { searching, collection, analysis } \\
\text { and processing of information }\end{array}$ & $\begin{array}{l}\text { Assessing the subject of } \\
\text { educational activity, } \\
\text { defining a common goal } \\
\text { and specific tasks, } \\
\text { choosing the adequate } \\
\text { means to solve tasks to } \\
\text { achieve the result, making } \\
\text { the necessary self-control, } \\
\text { using reference books and } \\
\text { technical documentation. }\end{array}$ & $\begin{array}{l}\text { A usage of } \\
\text { communicative } \\
\text { competence for an } \\
\text { effective cooperation in } \\
\text { different areas of } \\
\text { communication; selection } \\
\text { and systematization of } \\
\text { information materials } \\
\text { with a goal to } \\
\text { communicate in a } \\
\text { professional field. }\end{array}$ & $\begin{array}{l}\text { Take a responsibility } \\
\text { for professional } \\
\text { development, exercise } \\
\text { independence in } \\
\text { carrying out } \\
\text { independent } \\
\text { generalizations, make } \\
\text { independent decisions } \\
\text { and perform } \\
\text { independent actions in } \\
\text { overcoming learning } \\
\text { difficulties. }\end{array}$ \\
\hline
\end{tabular}

GC7. Ability to search for, process and analyses information from a variety of sources.

A knowledge of methods, techniques and technology of collecting information from various sources, analysis content of documents, analysis and data processing
Using technology and tools of search engines, methods of data mining and text, processing interpretation and synthesis of data.
Using the system of document-information communications to meet the information needed in the field of Computer Science and Information Technology.
Autonomy in the processing, interpretation and synthesis of data, responsibility for the timeliness, accuracy and reliability of presentation.

GC8. Ability to generate new ideas (creativity).

A knowledge of basic stages of the creative process, goals and objectives for their achievement, the mechanisms of the genesis and development of knowledge, methods of generating ideas, understanding of creativity as a universal process of unusual ideas generating.
Making professional

contacts and

Showing curiosity, appetite for risk, ability to think, get inspired by new ideas, implement them, light them around, combine and experiment. communication, adequate understanding of verbal and nonverbal communication signals, ability to overcome communication barriers.
Autonomy and responsibility for generating new ideas and decision making in the field of computer science in the development of methods, models, algorithms and their implementation.

GC9. Ability to work in a team.

GC10. Ability to be critical and self-critical.

GC11. Ability to design and projects manage.

\begin{tabular}{|c|c|c|c|}
\hline $\begin{array}{l}\text { A knowledge of the teamwork } \\
\text { principles, team values, } \\
\text { conflict foundations. } \\
\text { Knowledge management of IT } \\
\text { project methodology, PMBOK } \\
\text { standards, and software tools }\end{array}$ & $\begin{array}{l}\text { Carrying out the selection } \\
\text { and preparation of } \\
\text { information and tasks for } \\
\text { the project team, setting } \\
\text { goals, formulating } \\
\text { objectives for projects and }\end{array}$ & $\begin{array}{l}\text { The ability to plan } \\
\text { communication in a team } \\
\text { with customers, respect } \\
\text { correct behavior, } \\
\text { tolerance, rights, } \\
\text { acknowledgment thoughts }\end{array}$ & $\begin{array}{l}\text { The ability to express } \\
\text { thoughts while working } \\
\text { in a team, being } \\
\text { responsible for the } \\
\text { work team, the ability } \\
\text { to take responsibility to }\end{array}$ \\
\hline
\end{tabular}




\begin{tabular}{llll}
\hline Knowledge & Skills & Communication & $\begin{array}{l}\text { Autonomy } \\
\text { responsibility }\end{array}$ \\
\hline for IT projects managing. & programs implementation. & $\begin{array}{l}\text { af another person and the } \\
\text { ability to take part in the } \\
\text { proper debate, overcome } \\
\text { selfish attitudes, } \\
\text { principles of } \\
\text { self-criticism. }\end{array}$ \\
& & & \\
&
\end{tabular}

GC12. Ability to make reasoned decisions.

\begin{tabular}{|c|c|c|c|}
\hline $\begin{array}{l}\text { A professional knowledge } \\
\text { in Computer Science, } \\
\text { knowledge of } \\
\text { methodological approaches } \\
\text { to procedures for decision } \\
\text { making of organizational }\end{array}$ & $\begin{array}{l}\text { Conducting analysis of the } \\
\text { strengths and weaknesses of } \\
\text { the decision, analyzing the } \\
\text { opportunities and risks of } \\
\text { decisions, evaluating the } \\
\text { effectiveness of decisions. }\end{array}$ & $\begin{array}{l}\text { Conducting business } \\
\text { negotiations for the } \\
\text { transfer of information } \\
\text { using analysis, } \\
\text { reasoning and } \\
\text { counter-argumentation. }\end{array}$ & $\begin{array}{l}\text { The ability to take } \\
\text { responsibility for decisions, } \\
\text { including decisions in } \\
\text { unusual situations, the } \\
\text { ability to defend decision. }\end{array}$ \\
\hline
\end{tabular}
and managerial nature.

GC13. Ability to evaluate and maintain the quality of work produced.

\begin{tabular}{ll}
\hline $\begin{array}{l}\text { A knowledge of } \\
\text { international standards for } \\
\text { quality assessment software } \\
\text { and IT, model for }\end{array}$ & $\begin{array}{l}\text { Applying in the international } \\
\text { standards of quality } \\
\text { assessment software, }\end{array}$ \\
$\begin{array}{l}\text { evaluating the maturity of } \\
\text { software development }\end{array}$ & $\begin{array}{l}\text { services and IT management } \\
\text { of valuation models }\end{array}$ \\
processes, methods, quality & $\begin{array}{l}\text { of software development } \\
\text { assurance of IT systems. }\end{array}$
\end{tabular}

\section{A knowledge of} and IT, model for evaluating the maturity of software development assurance of IT systems.
The development of communications plans in the project; preparing and conducting meetings; problem diagnosis and conflicts during the work.
The ability to take responsibility for the quality of work, enforcement of contractual rights and obligations.

GC14. Determination and perseverance in the tasks given and responsibilities taken.

Analyzing problematic

situations, asking

The ability to adjust focused behavior by circumstances that prevent the achievement of goals, overcoming various obstacles. themselves specific goals for solving professional problems, choosing the path for future action, determining the means to achieve goals, making decisions.
The ability to develop communication in the team, find understanding in the implementation of individual tasks and fulfillment of obligations.
The ability to solve problems, develop design solutions taking uncertainty into account, develop appropriate guidance and regulations as well as proposals to implementing projects and programs.

GC15.Ability to act based on ethical reasoning.

A knowledge of the system of general rules of moral behavior and human groups of people, ethics, understanding the code of professional ethics.

\section{Implementing a system of} moral relations in professional activities.
The ability to plan and implement interpersonal communication based on certain moral principles.
The ability to take responsibility towards colleagues and the public the result of work, the ability to support the reputation of the group, compliance with moral prohibitions and requirements.

\section{Knowledge and skills for professional competencies in CS}

Professional competencies of bachelors in computer science based on fundamental and special training. The relationship between subject specific competencies, knowledge, skills and curriculum disciplines is shown in table 4. 
Table 4. Subject specific competencies, knowledge, skills and curriculum disciplines

\begin{tabular}{ll}
\hline $\begin{array}{l}\text { Subject } \\
\text { compet } \\
\text { encies } \\
\text { code }\end{array}$ & Knowledge \\
\hline & $\begin{array}{l}\text { A knowledge of theoretical and applied } \\
\text { provisions of continuous and discrete } \\
\text { analysis, including analysis of the } \\
\text { infinitely small, integral calculus, linear } \\
\text { algebra, analytic geometry, differential } \\
\text { equations, functional analysis, } \\
\text { combinatory, graph theory, Boolean } \\
\text { algebra. }\end{array}$ \\
\end{tabular}

\begin{tabular}{ll}
\hline & A knowledge of patterns and properties of \\
random phenomena, probability methods \\
of complex systems, basic concepts of \\
mathematical statistics, empirical data \\
processing methods, verification of \\
statistical hypotheses based on sample \\
data, elements of the theory of regression \\
and correlation.
\end{tabular}

\begin{tabular}{ll}
\hline & A knowledge of the basic concepts of the \\
theory of algorithms, formal models of \\
algorithms, primitive recursive, general \\
recursive and partially-recursive \\
functions, solvability and insolvability of \\
massive problems, the concepts of time \\
and space complexity of algorithms for \\
solving computational problems.
\end{tabular}

Skills

Disciplines
Effectively using modern mathematical tools in professional activities for solving theoretical, applied in the analysis, synthesis and projecting of information systems.
Mathematical analysis. Linear algebra and analytic geometry. Differential and integral calculus. Discrete mathematics

\section{Solving typical tasks using basic} theorems of probability theory; building distribution laws of random variables; building models of random processes and carrying out their analysis; applying probabilistic and statistical methods for evaluation of stochastic processes; using modern environment for solving statistical analysis of experimental data.

Using formal models and algorithms, computable functions, setting solvability, partial solvability and unsolvable algorithmic problems to project, develop and analyze algorithms, evaluating their performance and complexity

Using mathematical packages and developing programs of numerical methods implementation, reasonable choosing of numerical methods for solving engineering problems in the projecting and modeling of software and information systems and technologies, evaluating the effectiveness of numerical methods, including convergence, stability and complexity of implementation Formulating organizational goal for technical and economic systems management. Forming a system of quality control criteria; building a mathematical model of the problem, selecting and using the appropriate method for solving the optimization problem and finding its optimal solution. Making decisions about operations and the implementation of this decision,
Probability theory and mathematical statistics

\author{
Theory of \\ algorithms \\ The design and \\ analysis of \\ computer \\ algorithms
} methods; principles of organizational and technical systems and operations modeling; methods of solution of linear, integer, nonlinear, stochastic and dynamic programming; features of multiple tasks construction and solving.

A knowledge of concepts of operation, model operation and development operations stages; classification of (2020.03.003
Modeling of the systems and processes. Numerical Methods

\section{Operations Research} Mathematical optimization 
using software for searching of optimal

solutions of organizational and

economic governance.

A knowledge of system analysis methodology for a systematic study of deterministic and stochastic models of

SC6. objects and processes, projecting and operation of information systems, products, services, information technology and other objects of professional activity.

A knowledge of queuing models, Petri nets; probabilistic methodology and simulation facilities, processes and

SC7 systems; planning and conducting experiments with models of decision making to achieve the goal by the simulation results.

A knowledge of basic data structures and algorithms, methodologies and tools for object-oriented analysis and design, characteristics of different programming paradigms, principles, models, methods and technologies for the design and development of software products for various purposes.

A knowledge of principles, tools, web programming languages, technologies of creation of databases, repositories, data

SC9 marts and knowledge base for the development of distributed applications with integration of databases and data warehouses in a client-server architecture.

A knowledge of standards, methods, technology and process management lifecycle information and software systems, products and services of information technology.

A knowledge of methods and algorithms of analytical processing and data mining SC11 tasks for classification, prediction, cluster analysis, associative search rules using software tools to support data analysis.

$\mathrm{SC} 12$
A knowledge of computer architecture, operating systems (OS) functions,
Describing the subject area, for applying

the principles of system approach for

information systems and informatization

objects modeling and projecting, to

carrying out a systematic analysis of

business process management systems, uncertainty disclosing and analyzing multifactorial risks; finding solutions for weakly structured problems.

Identifying the components of structural and parametric identification of models of real systems, applying the modeling of complex objects and systems using appropriate software, assessing the completeness, adequacy, validity and feasibility models of real systems
Software models of subject media developing, choosing a programming paradigm from the standpoint of convenience and quality for implementing the use of methods and algorithms for solving problems in computer science for reliable and efficient software creation.
Using methods, technologies and tools for projecting and development of client-server applications, projecting conceptual, logical and physical models of databases, developing and optimizing queries which create distributed database repository and data marts, Knowledge base, including cloud

\section{Basics of \\ Programming \\ Programming \\ Functional \\ Programming \\ Logical \\ Programming}
Object-oriented
Relational
Database
Data Warehouses
Database
Development
Building a
Knowledge Base Modeling of the systems and processes Systems Analysis services.

Using methodologies, technologies and tools for lifecycle management of information systems, software, products and services of information technology in accordance with the requirements and restrictions of the customer, the ability to prepare project documentation (technical requirements, business plan, etc.)

Using, Text Mining, Web Mining technology for data mining; solving tasks using methods of classification, prediction, cluster analysis, associative rules search, Machine Learning, Neural Networks.

Solving issues of the administration, effective use, security, diagnostics,
Project

Management

Information

System Design

Software Design

Data Mining

Natural Language

Processing

Machine Learning

Neural Networks

Computer

Architecture 


\begin{tabular}{|c|c|c|c|}
\hline & $\begin{array}{l}\text { software interfaces for application access } \\
\text { to the operating system methods, } \\
\text { programming languages and system } \\
\text { software development methods that } \\
\text { interact with components of a computer } \\
\text { system. }\end{array}$ & $\begin{array}{l}\text { recovery, monitoring and optimization } \\
\text { of computers, operating systems and } \\
\text { system resources of computer systems. }\end{array}$ & $\begin{array}{l}\text { Operating } \\
\text { Systems } \\
\text { Computer } \\
\text { Systems. }\end{array}$ \\
\hline $\mathrm{SC} 13$ & $\begin{array}{l}\text { A knowledge of network technologies, } \\
\text { computer networks architecture, } \\
\text { technology networks and administration } \\
\text { of software in the implementation of } \\
\text { distributed computing. }\end{array}$ & $\begin{array}{l}\text { Possessing the methods and means of } \\
\text { work with computer networks; choosing } \\
\text { the configuration type and structure of a } \\
\text { computer network; operating computer } \\
\text { networks in the implementation of } \\
\text { distributed computing. }\end{array}$ & $\begin{array}{l}\text { Computer } \\
\text { Networks } \\
\text { Distributed } \\
\text { Computing. }\end{array}$ \\
\hline SK14 & $\begin{array}{l}\text { A knowledge of information security } \\
\text { concepts, principles of safe design IP and } \\
\text { IT, secure programming methodology, } \\
\text { threats and attacks, computer networks, } \\
\text { cryptography methods. }\end{array}$ & $\begin{array}{l}\text { Keeping confidentiality, integrity and } \\
\text { availability of information, ensure } \\
\text { authenticity, traceability and reliability } \\
\text { of information in terms of } \\
\text { incompleteness and uncertainty of input } \\
\text { data, multi-criteria professional tasks. }\end{array}$ & $\begin{array}{l}\text { Information } \\
\text { Security }\end{array}$ \\
\hline $\mathrm{SC} 15$ & $\begin{array}{l}\text { A knowledge of design methodology and } \\
\text { technology of complex systems, } \\
\text { CASE-tools system design, methods of } \\
\text { structural analysis, object-oriented design } \\
\text { methodology, project documentation, the } \\
\text { methodology for assessing the complexity } \\
\text { of developing complex systems. }\end{array}$ & $\begin{array}{l}\text { Using technology design of complex } \\
\text { systems, choosing CASE-tools; } \\
\text { formulating technical and economic } \\
\text { requirements, designing information and } \\
\text { software systems using templates and } \\
\text { automated design tools. }\end{array}$ & $\begin{array}{l}\text { IS and Software } \\
\text { Design } \\
\text { Modeling of } \\
\text { Business } \\
\text { Processes }\end{array}$ \\
\hline $\mathrm{SC} 16$ & $\begin{array}{l}\text { A knowledge of software architecture and } \\
\text { high-performance parallel and distributed } \\
\text { computing systems, numerical methods } \\
\text { and algorithms for parallel structures. }\end{array}$ & $\begin{array}{c}\text { The skills to form effective } \\
\text { communication strategies in the } \\
\text { performance of parallel and distributed } \\
\text { computing. }\end{array}$ & $\begin{array}{l}\text { Parallel and } \\
\text { Distributed } \\
\text { Computing }\end{array}$ \\
\hline
\end{tabular}

\section{Conclusions}

The experience of developed countries shows that in the modern world, science and education are becoming main structural factors of the modern economy. An important task is the development of IT education as a driving factor for the entire educational system.

One of the major challenges, which higher IT education faces, is the need to reduce the gap between theoretical knowledge and practical skills and to make the educational process flexible and adequate to ever-changing needs.

Thanks to the standards of CS bachelor's level studies Ukraine has received the European level-bachelor's degree program in Computer Science, which is harmonized with the requirements of the IT industry in Ukraine and the European requirements for IT professions.

The prospect of further research lies in finding ways and developing models for effective adaptation of students of IT specialties to the business processes of IT companies within the competency education paradigm.

\section{References}

[1] ALaw of Ukraine "About the priority directions of development of science and technology" of July 11, 2001 No. 2623-III. Available in: https://cis-legislation.com/document.fwx?rgn=18116/. Last accessed 2019/01/15.

[2] Marta Hlova. Ukrainian software. development industry: year in review, prospects for 2019. Available in: https://www.n-ix.com/ukrainian-software-development-industry-year-review-prospects-2019/. Last accessed 2019/10/20.

[3] Budget-2018: Development by inertia. Express analysis. Available in: https://ain.ua/en/2019/02/15/it-industry-of-ukraine-and-eastern-europe/]. Last accessed 2010/02/18 
[4] Ukraine has become Europe's \#1 IT outsourcing and software development powerhouse. Available in:

https://escadra.com.ua/en/ukraina-zanyala-pervoe-mesto-v-evrope-v-otrasli-it-autsorsinga-i-razrabotki-po.html/. Last accessed 2019/08/10

[5] Curricula Recommendations. Available in: https://www.acm.org/education/curricula-recommendations. Last accessed 2018/11/20.

[6] T. Kovaliuk, O. Chaikovska. Educational programs and Professional Standards in the IT field as factors of development of IT education. Modern information systems. (2018). Vol. 2, No. 2, pp.47- 54.

[7] Zatverdzheni standarty vyshchoyi osvity. Available in:

https://mon.gov.ua/ua/osvita/visha-osvita/naukovo-metodichna-rada-ministerstva-osviti-i-nauki-ukrayini/zatverdzheni-standarti -vishoyi-osviti. Last accessed 2019/07/25

[8] Curriculum Guidelines for Undergraduate Degree Programs in Computer Science. Available in: https://www.acm.org/binaries/content/assets/education/cs2013_web_final.pdf

[9] Nakaz MON Ukrayiny vid 01.06.2016 No 600 "Pro zatverdzhennya ta vvedennya v diyu Metodychnykh rekomendatsiy shchodo rozroblennya standartiv vyshchoyi osvity". Available in:

https://mon.gov.ua/storage/app/media/vishcha-osvita/rekomendatsii-1648.pdf. Last accessed 2019/10/12

[10] Tuning Educational Structures in Europe. Available in: http://www.unideusto.org/tuningeu/. Last accessed 2019/10/12

[11] V.M. Zakharchenko, V.I. Luhovyy, YU.M. Rashkevych, ZH.V. Talanova. Rozroblennya osvitnikh prohram. Metodychni rekomendatsiyi. Kyiv. DP «NVTS «Priorytety». (2014).

[12] Tuning Educational Structures in Europe. Final Report. Available in: http://tuningacademy.org/wp-content/uploads/2014/02/TuningEUI_Final-Report_EN.pdf

[13] J. Lokhoff. A Tuning Guide to Formulating Degree Programme Profiles. Bilbao, Groningen and The Hague (2010).

[14] Standards and Guidelines for Quality Assurance in the European Higher Education Area (ESG). - K.: CS Ltd., 2015. Available in: https://erasmusplus.org.ua/images/phocadownload/standards-and-guidelines_for_qa_in_the_ehea_2015.pdf. Last accessed 2018/04/22.

[15] International Standard Classification of Education (ISCED 2011): UNESCO Institute for Statistics Available in: http://uis.unesco.org/sites/default/files/documents/international-standard-classification-of-education-isced-2011-en.pdf .

[16] On approval of the National Qualifications Framework. Resolution No 1341 dated November 23, 2011, Kyiv. 